\title{
Agrobiodiversity and in situ conservation in quilombola home gardens with different intensities of urbanization
}

\author{
Julia Vieira da Cunha Ávila ${ }^{12^{\star}}$, Anderson Santos de Mello ${ }^{3}$, Mariane Elis Beretta ${ }^{4}$, Rafael Trevisan $^{5}$, Pedro Fiaschi $^{5}$ \\ and Natalia Hanazaki ${ }^{2}$
}

Received: August 15, 2016

Accepted: November 17, 2016

\begin{abstract}
Among the agricultural environments of traditional communities, home gardens are frequently cited as high agrobiodiversity sites. However, the agrobiodiversity of home gardens along a rural-urban gradient demands study in order to identify possible influences of urbanization and to support mitigation of impacts. The present work investigated the role home gardens play in the in situ agrobiodiversity conservation of plants in quilombola communities with different degrees of urbanization. The study found that more urbanized communities have larger home gardens, but the average richness of plant species in these areas was not statistically different among the communities. Furthermore, the abundance of plant species was similar. Medicinal and food plants were mainly found in home gardens of the communities with high to intermediate levels of urbanization, while ornamental plants were more common in rural community home gardens. It is believed that crop exclusivity in home gardens of the more urbanized communities highly influenced the results, increasing the role home gardens play in maintaining traditional practices. The elevated and statistically equal species richness in home gardens suggests that, despite the factors generated by urbanization, all of the communities are very important for in situ conservation of native and introduced species.
\end{abstract}

Keywords: ethnobotany, interspecific diversity, rural-urban gradient, traditional community, yard

\section{Introduction}

Home gardens are the most widespread use of land worldwide (Howard et al. 2006; Kumar \& Nair 2006), are often located on the property of individual houses and managed by families (Fernandes \& Nair 1986; Vogl et al. 2004), and can help meet local demands (Kumar \& Nair 2004; Kumar \& Nair 2006). According to Saragoussi et al. (1988), the term "home garden" refers to the area of land surrounding a house and, in most cases, is defined as the portion of land near the house that is easy to access where many species are cultivated, for example, for food, medicine and wood.

In urban areas, home gardens are part of a landscape mosaic and can play a significant role in pollination (Kearns et al. 1998; Biesmeijer et al. 2006) and ecosystem services that involve the remaining landscape, such as seed dispersal and pest control (Andersson et al. 2007), and are important in the formation and maintenance of microclimates (Castro 1995).

\footnotetext{
${ }^{1}$ Instituto de Desenvolvimento Sustentável Mamirauá, P.O Box: 3869553225, 69553-225, Tefé, AM, Brazil

${ }^{2}$ Programa de Pós-Graduação em Ecologia, Universidade Federal de Santa Catarina, campus Trindade, 88010-970, Florianópolis, SC, Brazil

${ }^{3}$ Programa de Pós-Graduação em Botânica, Universidade Federal do Rio Grande do Sul, 91501-970, Porto Alegre, RS, Brazil

${ }^{4}$ Servidão Dunas da Joaquina, 100, Rio Tavares, 88048-424, Florianópolis, SC, Brazil

${ }^{5}$ Programa de Pós-Graduação em Biologia de Fungos, Algas e Plantas, Universidade Federal de Santa Catarina, campus Trindade, 88010-970, Florianópolis, SC, Brazil
}

*Corresponding author: biojuba@gmail.com 
One of the main purposes of a home garden is to produce food (Fernandes \& Nair 1986), and the high agrobiodiversity found in these areas increases the nutritional diversity and quality of family diets (Faber \& Benadé 2003; Johns $\&$ Sthapit 2004). From an ecological perspective, these areas are considered sustainable systems of management (Fernandes \& Nair 1986; Alcorn 1990), can house endangered species, contributing to the conservation of native species (Blanckaert et al. 2004; Kumar \& Nair 2004), and can serve as experimental and observation areas of recently acquired species (Niñez 1987; Kumar \& Nair 2004; Aguilar-Støen et al. 2009).

Vasconcellos (2004) noted that home gardens can function as places that retain genetic erosion because they conserve varieties of crops displaced by commercial hybrid and transgenic varieties, and are also experimental sites for the managers. Additionally, home gardens can represent a legacy of traditional farming practices, where knowledge has been passed down and socially accumulated, often for many generations (Nolin 2003).

Among the agricultural environments of traditional communities, such as cultivated, permanent and fallow fields, home gardens are often places that have high agrobiodiversity (Kehlenbeck \& Maass 2004; Trinh et al. 2003; Miller et al. 2006; Sunwar et al. 2006; Pandey et al. 2007). Home gardens maintain high interspecific and intraspecific diversity, the result of experimentation, local selection and exchanges and movement of species taken from one environment to another (Williams 1997), which can reduce the vulnerability of species to humans, biological impacts and climate change (Kumar \& Nair 2004; Tompkins \& Adger 2004).

Furthermore, the relationship between sociodiversity and biodiversity includes the possibility of in situ conservation of agrobiodiversity, preserving the cultural heritage of traditional populations and connecting traditional management knowledge to strategies to guarantee the territorial rights of these groups. The Convention on Biological Diversity (CBD) defines in situ conservation as "the conservation of ecosystems and natural habitats and the maintenance and recovery of viable populations of species in their natural surroundings and, in the case of domesticated or cultivated species, in the surroundings where they have developed their distinctive properties" (UNCED 1992). In this regard, it is important to think about conservation strategies that maintain agrobiodiversity, and humans play an important role in maintaining and increasing this at the local level (Emperaire \& Peroni 2007; Emperaire et al. 2008).

For this reason, home gardens are increasingly recognized as in situ conservation areas of agrobiodiversity (Perrault-Archambault \& Coomes 2008) because they can preserve vital resources for humanity, provide economic and nutritional benefits (Thrupp 2000; Eyzaguirre \& Linares 2004; Kumar \& Nair 2006), and contribute to knowledge about the distribution (geographically and socially) of cultivated species. Additionally, socioeconomic data linked to ecological data can help identify factors that influence species diversity (Bellon 1996; 2004; Zimmerer 1996).

In Brazil, home gardens are common in both rural and urban areas (Castro 1995; Florentino \& Albuquerque 2007; Carniello et al. 2010; Garcia et al. 2015). Although agrobiodiversity is thought to decline as urbanization increases, information about this is scarce (Poot-Poll et al. 2015), which is very worrying in populated regions where there is real estate speculation, such as coastal areas of the country.

Poot-Poll et al. (2015) emphasizes that the relationship between rural conditions and agrobiodiversity assumes complex forms (Poot-Poll et al. 2015) and, as noted by Galluzzi et al. (2010), agrobiodiversity along a rural-urban gradient needs further study. Avila et al. (2015) found that, along a rural-urban gradient, home gardens are the main places where quilombola communities obtain their resources. Over the past decades, populations of African descendants in Brazil have been recognized for their traditionalism. These traditional communities, called quilombolas, are descendants of African slaves and possess an intimate relationship with the land, using it to constitute their social and economic cultures and transmit material and immaterial goods (SEPPIR 2015).

The present study investigated the role that home gardens play in in situ conservation of quilombola communities with different degrees of urbanization and asked the following questions: How does the size of home gardens vary in rural and urban locations? How do the richness and abundance of plant species that are grown in rural and urban home gardens vary? What is the origin of the species in home gardens? We hypothesized that more rural communities have larger home gardens that maintain a higher richness and abundance of plants, with a higher number of native species.

\section{Materials and methods}

\section{Study Area}

The coastal quilombola communities of Santa Catarina are poorly studied and there is no research about their relationship with plants and the sites where plants are obtained. They are located in the central coastal region of the state, in the municipalities of Garopaba (Morro do Fortunato and Aldeia communities) and Paulo Lopes (Santa Cruz community), which are within the Atlantic Forest biome (IBGE 2004). The original vegetation of this area included dense ombrophilous forest and pioneer formations called restinga (IBGE 2012). Fortunato was recognized as a quilombola territory in 2006, Aldeia in 2010 and Santa Cruz in 2007 (Brasil 2014); however, the territories still need to be officially demarcated. 
These communities are in different urban situations. They were classified as rural, intermediate and urban according to the percentage of urban area in $3.5 \mathrm{~km}^{2}$. In this space, Aldeia, Santa Cruz and Fortunato have urban areas of $36 \%, 17 \%$ and $2 \%$, respectively. Aldeia ( $28^{\circ} 06^{\prime} 23^{\prime \prime S}$, $48^{\circ} 40^{\prime} 43^{\prime \prime} \mathrm{W}$ ) is the most urbanized community. Fortunato ( $28^{\circ} 01^{\prime} 21^{\prime \prime} \mathrm{S}, 48^{\circ} 39^{\prime} 52^{\prime \prime} \mathrm{W}$ ) is the most rural and occurs approximately $7 \mathrm{~km}$ from the center of Garopaba on the side of a hill, surrounded by vegetation. Santa Cruz ( $27^{\circ} 58^{\prime} 24^{\prime \prime}$, $48^{\circ} 41^{\prime} 16^{\prime \prime} \mathrm{W}$ ), which is located near the center of Paulo Lopes, is partially urbanized compared to the other two communities (Avila et al. 2015).

Each community has around 30 to 35 residences and 90 to 130 residents. Fortunato has the most native vegetation, which has increased over recent decades due to a decrease in agricultural practices and because residents have been searching for salaried jobs; the amount of native vegetation in Aldeia and Santa Cruz has decreased due to urbanization and deforestation (Zank et al. 2016). Fortunato still has the largest percentage of people who get income from farming (Avila et al. 2015). General characteristics of these communities are described by Avila et al. (2015).

This study was approved by the Ethics Committee in research with human beings at the Universidade Federal de Santa Catarina (18847013.0.0000.0121 on August 14, 2013) and access to traditional knowledge was authorized by IPHAN (01450.012607/2013-20). The participation of the informants was conditional to their prior informed consent (Avila et al. 2015).

\section{Data collection}

Data collection occurred from August 24, 2013 to March 09, 2014. Home gardens of all quilombola families were investigated. This study considered the home garden as part of the terrain that the residents recognized as the land around their house, including parts without plants that were within the area. For each family unit (residence), at least one person indicated the area of their home garden. In each home garden, all plants were surveyed and the area was measured using a $30 \mathrm{~m}$ or $50 \mathrm{~m}$ measuring tape. Abundance was recorded for woody and herbaceous species taller than $40 \mathrm{~cm}$, where ramets were counted as individuals. These plants were collected and photographed so they could be identified. The residents were asked about the common names of each plant found. For Manihot esculenta Crantz. (sweet manioc and bitter manioc), they were also asked about the variety they had in their home garden because there are many studies about manioc and traditional systems in Brazil that have focused on the Atlantic coast and processes of increasing the number of varieties of this species (Peroni 2004).

The herbaceous plants (except grasses) that were spontaneous and shorter than $40 \mathrm{~cm}$ were sampled for richness within five $1 \mathrm{~m}^{2}$ squares (one square on each side of the house and a fifth square on one of the sides). All of the squares were at least 3 meters apart. In each square, herbaceous individuals were counted. If the home garden occurred on less than 4 sides of the house additional squares were added to the sides with a part of the home garden (following the conditions above). The same sampling procedures used for the woody and herbaceous plants taller than $40 \mathrm{~cm}$ were used for the herbs shorter than $40 \mathrm{~cm}$. The information about how species from the home gardens are used was analyzed based on data taken from ethnobotanical questionnaires in Avila et al. (2015), where all inhabitants who agreed with the research were interviewed using free listings about known plant species. The plants collected were processed following conventional methods used in plant taxonomy (Fidalgo \& Bononi 1989), and identified by consulting taxonomists from the Department of Botany at the Federal University of Santa Catarina and comparing specimens at the herbarium FLOR. Botanical collections were deposited in FLOR and EAFM (Thiers, B. continuously updated). The names of plants and plant families were confirmed using the Flora of Brazil (List of Flora of Brazil 2015) and Missouri Botanical Garden (MOBOT 2015) databases. Information about the origin of the species identified is from the Flora of Brazil (List of Flora of Brazil) and Reis et al. (2011).

To compare the average size of the home gardens and the number of plant species in each community, ANOVA and Tukey's test were used.

\section{Results}

In total, the home gardens of 26 families in the Aldeia community, 17 in the Santa Cruz community and 28 in the Fortunato community were analyzed. Aldeia, despite being the most urban, had the largest home gardens, on average (Tab. 1). However, this average had a high standard deviation, and it was also found that size among the home gardens in Aldeia had a higher contrast. Average home garden size in the Aldeia and Fortunato communities

Table 1. Size of the home gardens and richness of plant species identified in each quilombola community studied.

\begin{tabular}{|l|c|c|c|}
\hline & Aldeia & Santa Cruz & Fortunato \\
\hline Number of home gardens & 26 & 17 & 28 \\
\hline Number of plant species & 348 & 161 & 265 \\
\hline Average size of home gardens & $978 \mathrm{~m}^{2}$ & $350 \mathrm{~m}^{2}$ & $419 \mathrm{~m}^{2}$ \\
\hline Standard deviation of home gardens size & $533 \mathrm{~m}^{2}$ & $119 \mathrm{~m}^{2}$ & $155 \mathrm{~m}^{2}$ \\
\hline
\end{tabular}


differed in a statistically significant way (Fig. 1), showing that the home gardens of the community closest to urban areas are larger in relation to more distant communities.

The greatest number of plant species found in home gardens (Tab. 1) was in the Aldeia community $(\mathrm{n}=26)$, which was based on a total of 348 species (average of 13.38 species per home garden). In Santa Cruz ( $\mathrm{n}=17) 161$ species (average of 9.47) were identified, and in Fortunato $(\mathrm{n}=28)$ 265 species (average of 9.46) were identified.

Species richness in the home gardens of Aldeia and Santa Cruz differed between each other $(p<0.05)$, but those of Fortunato did not differ from the other communities (Fig. 2). Thus, despite having different home garden sizes, species richness in the home gardens of the communities closest and furthest to urban centers did not differ.

In this section the Aldeia, Fortunato and Santa Cruz communities are represented by the letters "A", "F" and "S," respectively. In the home gardens of all the communities there was a higher percentage of medicinal species $(A=34 \%$, $\mathrm{S}=32 \%, \mathrm{~F}=31 \%$ ), followed by food plants ( $\mathrm{A}=22 \%, \mathrm{~S}$ $=20 \%, \mathrm{~F}=20 \%$ ).

In the home gardens of Aldeia, the most frequent plants were used for food, such as Psidium guajava, Allium fistulosum, Musa sp., Citrus sinensis and Eriobotrya japonica, as well as medicinal plants, such as Plectranthus barbatus, and plants used for shade, such as Schinus terebinthifolius (Tab. 2). In Santa Cruz, food plants stood out, such as Musa sp., Psidium guajava, Syzygium cumini, Eriobotrya japonica, Citrus sinensis and Eugenia uniflora, as well as plants used in rituals, such as Dieffenbachia amoena. In Fortunato, ornamental plants, such as orchids (Orchidaceae), Syngonium angustatum, bromeliads (Bromeliaceae) and Rosa spp., were more prominent, as well as shade plants, such as Schinus terebinthifolius, food plants, such as citrus trees (Citrus spp.), and plants used in rituals, such as Dieffenbachia amoena.

The family Asteraceae was prominent in all three communities. For Aldeia, the most common plant families were Poaceae, Rutaceae (seven species), Asteraceae (29 species), Lamiaceae (15 species) and Myrtaceae (eight species), for Santa Cruz the families were Asteraceae (22 species), Malvaceae (three species), Myrtaceae (five species), Poaceae and Asparagaceae (nine species), and for Fortunato the families were Poaceae, Asteraceae (24 species), Araceae (one species), Rosaceae (seven species) and Myrtaceae (seven species).

The analysis of herbaceous plants shorter than $40 \mathrm{~cm}$ revealed that some of the sampling units $(A=16 \%, S=67 \%$ and $\mathrm{F}=24 \%$ ) had no plants (i.e., were characterized by bare land). Thus, based on the higher percentage of bare land, the herbaceous vegetation is managed less in Santa Cruz than in the other communities.

In Aldeia, the most abundant cultivated plants and trees were principally used for human food, such as Manihot esculenta, Zea mays, Musa sp., Allium fistulosum, Carica papaya, Saccharum sp. and Arachis hypogaea. In addition,

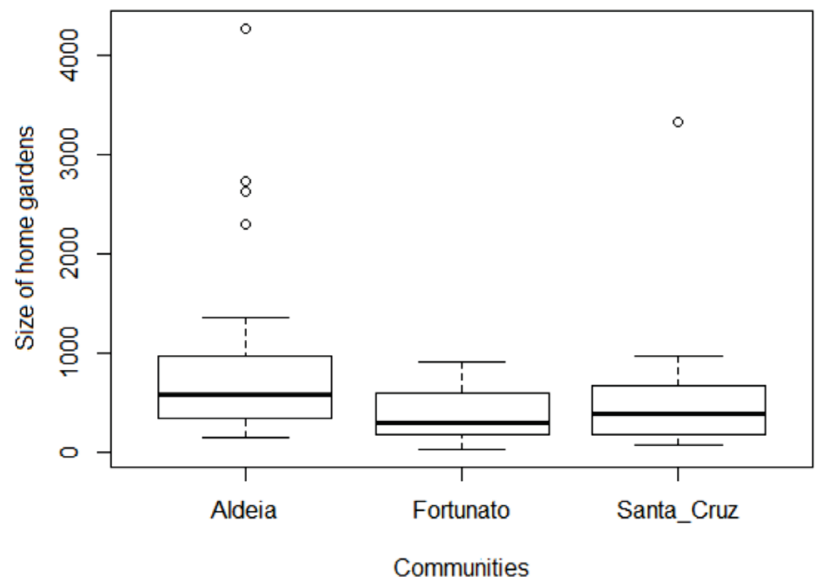

Figure 1. Average size $\left(\mathrm{m}^{2}\right)$ of the home gardens of the communities studied.

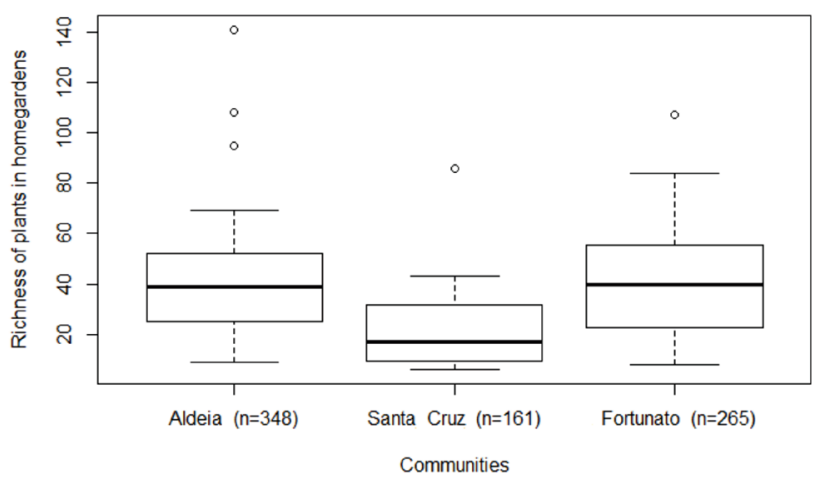

Figure 2. Average number of plant species (richness) in the home gardens of the communities studied.

one species of ritual and spiritual importance, Sansevieria trifasciata, was abundant; it is used to help protect houses from spirits (Tab. 2).

In Santa Cruz, the most abundant plants were Saccharum sp., Musa sp. and Manihot esculenta, used as food, as well as Leonotis nepetifolia, Schefflera arboricola and Sansevieria trifasciata, used as ornamentals and in rituals. In Fortunato, some of the most abundant plants were Sansevieria trifasciata, Dieffenbachia amoena and Petiveria alliacea, also plants important in rituals because they are used help protect houses from spirits. Food plants, such as Musa sp., Saccharum sp., Fragaria sp., Zea mays, Xanthosoma robustum/X. sagittifolium and Allium fistulosum, were also abundant plants in the home gardens.

More than half ( $\mathrm{A}=67 \%, \mathrm{~S}=56 \%, \mathrm{~F}=65 \%)$ of the species identified in the home gardens are exotic. However, 114 species (Aldeia), 70 species (Santa Cruz) and 92 species (Fortunato) are native to Brazil and conserved in the home gardens of the communities.

In all of the communities studied, food plants cultivated in larger areas and in greater abundance (called roças) were also observed in home gardens, mainly bananas $(A=10, S$ 
Table 2. Presence (in percentage) and relative abundance of principal species in home gardens of the quilombola communities studied.

\begin{tabular}{|c|c|c|c|c|c|c|c|}
\hline \multirow[t]{2}{*}{ Species } & \multirow[t]{2}{*}{ Family } & \multicolumn{2}{|c|}{ Aldeia } & \multicolumn{2}{|c|}{ Santa Cruz } & \multicolumn{2}{|c|}{ Fortunato } \\
\hline & & $\begin{array}{c}\text { Presence in } \\
\text { homegardens } \\
\text { (n=26 home } \\
\text { gardens) }\end{array}$ & $\begin{array}{c}\text { Relative } \\
\text { abundance } \\
(\mathrm{n}=5794)\end{array}$ & $\begin{array}{l}\text { Presence in } \\
\text { homegardens } \\
\text { ( } \mathrm{n}=17 \text { home } \\
\text { gardens) }\end{array}$ & $\begin{array}{l}\text { Relative } \\
\text { abundance } \\
(\mathrm{n}=2924)\end{array}$ & $\begin{array}{c}\text { Presence in } \\
\text { homegardens } \\
\text { ( } \mathrm{n}=28 \text { home } \\
\text { gardens) }\end{array}$ & $\begin{array}{c}\text { Relative } \\
\text { abundance } \\
(\mathrm{n}=5088)\end{array}$ \\
\hline several species & Poaceae & $78 \%$ & - & $41 \%$ & - & $68 \%$ & - \\
\hline Psidium guajava L. & Myrtaceae & $59 \%$ & 0.0057 & $47 \%$ & 0.0168 & $57 \%$ & 0.0086 \\
\hline Allium fistulosum L. & Amaryllidaceae & $52 \%$ & 0.0368 & $24 \%$ & 0.0147 & $25 \%$ & 0.0206 \\
\hline Musa sp. & Musaceae & $48 \%$ & 0.0878 & $47 \%$ & 0.0913 & $43 \%$ & 0.1018 \\
\hline Richardia sp. & Rubiaceae & $48 \%$ & - & $12 \%$ & - & $4 \%$ & - \\
\hline Schinus terebinthifolius Raddi & Anacardiaceae & $44 \%$ & 0.0060 & $29 \%$ & 0.0058 & $54 \%$ & 0.0069 \\
\hline Citrus sinensis (L.) Osbeck & Rutaceae & $44 \%$ & 0.0069 & $29 \%$ & 0.0031 & $36 \%$ & 0.0043 \\
\hline Citrus spp. 3 & Rutaceae & $44 \%$ & - & $18 \%$ & - & $29 \%$ & - \\
\hline Eriobotrya japonica (Thunb.) Lindl. & Rosaceae & $41 \%$ & 0.0036 & $35 \%$ & 0.0068 & $50 \%$ & 0.0059 \\
\hline Plectranthus barbatus Andrews & Lamiaceae & $41 \%$ & 0.0019 & $12 \%$ & 0.0031 & $14 \%$ & 0.0014 \\
\hline Phyllanthus spp. & Phyllanthaceae & $37 \%$ & - & $18 \%$ & - & $36 \%$ & - \\
\hline Syngonium angustatum Schott & Araceae & $33 \%$ & 0.0097 & $29 \%$ & 0.0056 & $61 \%$ & 0.01198 \\
\hline several species & Orchidaceae & $30 \%$ & - & $24 \%$ & - & $61 \%$ & - \\
\hline Bidens spp. & Asteraceae & $26 \%$ & - & $47 \%$ & - & $39 \%$ & - \\
\hline Sida planicaulis Cav. & Malvaceae & $26 \%$ & - & $53 \%$ & - & $18 \%$ & - \\
\hline Eugenia uniflora L. & Myrtaceae & $26 \%$ & 0.0021 & $29 \%$ & 0.0034 & $43 \%$ & 0.0053 \\
\hline Saccharum sp. & Poaceae & $26 \%$ & 0.0250 & $24 \%$ & 0.2808 & $25 \%$ & 0.0482 \\
\hline Rosa spp. & Rosaceae & $26 \%$ & 0.0090 & $18 \%$ & 0.0034 & $57 \%$ & 0.0094 \\
\hline Citrus spp. 1 & Rubiaceae & $26 \%$ & 0.0017 & $12 \%$ & 0.0003 & $57 \%$ & 0.0033 \\
\hline Drymaria cordata (L.) Willd. ex Schult. & Caryophyllaceae & $22 \%$ & - & - & - & $57 \%$ & - \\
\hline Dieffenbachia amoena Bull. & Araceae & $22 \%$ & 0.0050 & $35 \%$ & 0.0537 & $57 \%$ & 0.0841 \\
\hline Sansevieria trifasciata Prain & Asparagaceae & $22 \%$ & 0.0262 & $29 \%$ & 0.0284 & $32 \%$ & 0.1659 \\
\hline Carica papaya L. & Caricaceae & $22 \%$ & 0.0316 & $24 \%$ & 0.0079 & $36 \%$ & 0.0132 \\
\hline Manihot esculenta Crantz & Euphorbiaceae & $22 \%$ & 0.1519 & $24 \%$ & 0.0544 & $7 \%$ & 0.0028 \\
\hline Commelina erecta L. & Commelinaceae & $22 \%$ & - & $12 \%$ & - & $93 \%$ & - \\
\hline Canna sp. & Cannaceae & - & - & $35 \%$ & 0.0298 & $25 \%$ & 0,0208 \\
\hline Leonotis nepetaefolia (L.) R. Br. & Lamiaceae & - & - & $12 \%$ & 0.0862 & $4 \%$ & 0.0024 \\
\hline Bromeliaceae & Bromeliaceae & $19 \%$ & - & $12 \%$ & - & $57 \%$ & - \\
\hline Bambusoideae, several species & Poaceae & $19 \%$ & 0.0364 & $6 \%$ & 0.0012 & $1 \%$ & 0.0002 \\
\hline Zea mays L. & Poaceae & $11 \%$ & 0.0873 & - & - & $7 \%$ & 0.0244 \\
\hline Petiveria alliacea L. & Phytolaccaceae & $11 \%$ & 0.0028 & $29 \%$ & 0.0133 & $25 \%$ & 0.0242 \\
\hline Schefflera arboricola (Hayata) Merr. & Araliaceae & $11 \%$ & 0.0045 & $6 \%$ & 0.0003 & $36 \%$ & 0.0039 \\
\hline Nephrolepis sp. & Davalliaceae & $11 \%$ & 0.0007 & $6 \%$ & 0.0003 & $29 \%$ & 0.0348 \\
\hline Fragaria sp. & Rosaceae & $7 \%$ & 0.0022 & - & - & $7 \%$ & 0.0252 \\
\hline Syzygium cumini (L.) Skeels & Myrtaceae & $7 \%$ & - & $41 \%$ & - & $4 \%$ & 0.0002 \\
\hline Vernonia polyanthes (Spreng.) Less. & Asteraceae & $4 \%$ & 0.0007 & $41 \%$ & 0.0506 & $4 \%$ & 0.0002 \\
\hline
\end{tabular}

$=6, \mathrm{~F}=10)$, bitter manioc $(\mathrm{A}=5, \mathrm{~S}=2, \mathrm{~F}=1)$, sugarcane $(\mathrm{A}$ $=4, \mathrm{~S}=2, \mathrm{~F}=4)$, corn $(\mathrm{A}=2, \mathrm{~F}=2$ ) and taiá (Xanthosoma robustum or Xanthosoma sagittifolium) $(\mathrm{F}=4)$. In the case of Aldeia and Fortunato, there were also cultivated fields (roças) outside of the home gardens. In Aldeia, three people were cultivating bitter manioc on leased land, and in Fortunato the cultivated areas were within the territory; one person had an area of bananas (Musa sp.), another had manioc (both sweet and bitter varieties), six had areas of sugarcane (Saccharum sp.), one person had a plantation of passion fruit (Passiflora spp.), another produced strawberries (Fragaria sp.) and one person had a plantation of vegetables, including lettuce (Lactuca sativa), kale (Brassica oleracea), arugula (Eruca sativa), watercress (Nasturtium officinale), cabbage (Brassica oleracea), carrots (Daucus carota), parsley (Petroselinum crispum) and chives (Allium fistulosum).

In Aldeia, the Manihot esculenta plants in the home gardens $(n=6)$ were the sweet manioc. Bitter manioc was planted outside of the home gardens on leased land, separately or in the same space as sweet manioc. Nowadays all bitter manioc produced is used as cattle food, which might explain why this variety is grown near pastures and outside the community. It was also explained that until three years before the study bitter manioc was used to produce flour, but for more than seventeen years the community mill has not worked so the only option is to produce flour using the 
mill owned by the municipality. However, because part of the flour produced has to be given to the municipality as a payment for use of the mill, the residents told us that it is not worth doing it anymore.

In Santa Cruz, four people had Manihot esculenta in their home garden, three with sweet manioc and one with only bitter manioc. As with Aldeia, the production of bitter manioc was used exclusively for animal food. In the case of sweet manioc, the residents mentioned cases of theft, which discouraged cultivating this plant.

In Fortunato, only two people had Manihot esculenta in their home garden (both sweet manioc). Moreover, only one person had cultivated bitter manioc in a field. Residents reported that more bitter manioc was cultivated in the past but presently only a small quantity is grown and used to produce flour.

\section{Discussion}

The home gardens were larger in the more urbanized community (Aldeia) compared to the less urbanized community (Fortunato). In urban regions, this may reflect the lower availability of arable land outside of home gardens because, in the case of Aldeia, more homogeneous plantings of food species (generally found in a field) need to be grown in home gardens.

Vasconcellos (2004) noted that the quantity of plants available in a home garden is related to social, cultural, economic and environmental values. In this sense, Fortunato has a higher diversity of fields and a large garden on land outside of the home gardens, which is mainly used for commercial purposes, except for bitter manioc and sweet manioc that are cultivated as food for the residents, and sugarcane that is grown as cattle food. This might be the reason why plant richness in the home gardens among the communities under different degrees of urbanization did not statistically differ.

Moreno-Black et al. (1996) stressed that using fields to cultivate plants on a daily basis can reduce the need for home gardens and, therefore, an increase in urban conditions could contribute to greater agrobiodiversity in these environments to compensate for the lack of additional land. This result reinforces the idea that the more urbanized the community, the fewer environments there are to cultivate and collect plants and the more the community relies on home gardens. Furthermore, it is still necessary to investigate how the number of people working in a home garden affects its size, richness and efficiency. The most urbanized community (Aldeia) knew the most about the plants and their uses compared to the other communities (Avila et al. 2015), which can be associated with the number of plants found in the home gardens of this community. Despite the quilombolas dealing with distinct contexts along an urbanization gradient, their home gardens proved to be important locations for in situ conservation of biodiversity and for maintaining traditional practices, especially the cultivation of manioc and medicinal plants.

In urban home gardens of the Praia Grande quilombola community (São Paulo, Brazil), Vasconcellos (2004) noted that the average number of species in home gardens was 17.69. Eichemberg (2003), in an urban area of Rio Claro (São Paulo, Brazil), found an average of 24.11 species. In addition, Brito (1996) recorded an average of 17.53 species in an urban area of Aripuanã (Mato Grosso, Brazil). For studies in rural environments, Garrote (2002) recorded 10.58 species in home gardens of the traditional community of Saco do Mamanguá, in Paraty (Rio de Janeiro, Brazil). Based on the averages cited in these works, for both urban and rural home gardens, we know the average number of species in the home gardens of the present study is close to the averages found for other locations. Sometimes the average is lower, which could be related to better access to markets and fairs and because some people live in more urban areas.

While studying semi-rural and rural communities, PootPool et al. (2015) found that semi-rural communities had an abundance of plants in relation to semi-urban communities, which is different from what was observed among the quilombolas. A higher intensity of management in these environments and a greater use of plant resources as a source of income in the Aldeia and Fortunato communities could have influenced this result.

Differences in floristic and structural composition among conditions of rurality can suggest different uses for home gardens, where rural home gardens tend to maintain a function of subsistence, possessing species used for diverse needs, such as food and medicine (Arifin et al. 1998; Kehlenbeck et al. 2007; Cilliers et al. 2013; Mosina 2014; Poot-Pool et al. 2015;), and peri-urban home gardens tend to accentuate services related to ornamental species (Kumar \& Nair 2004; Cilliers et al. 2013; Poot-Pool et al. 2015). This occurs, in part, because residents earn a relatively high income from various non-agricultural economic activities, which allows them to favor the hedonic and esthetic contributions of home gardens (Arifin et al. 1998; Kehlenbeck et al. 2007; Cilliers et al. 2013; Mosina 2014).

However, among the quilombolas, the intermediate and urban communities stood out because of the presence of food and medicinal plants in their home gardens, which shows that these spaces are centers for the management of plant resources used for subsistence. This is justifiable because there is a lack of space to cultivate plants in other locations, and because the quilombolas historically cultivated plant resources and have an interest in continuing these activities, despite urban expansion, by combining these traditional practices with other sources of income whenever possible.

The rural quilombola community had the most ornamental plants in their home gardens, which could be associated with a higher number of fields and gardens outside of the home gardens. Still, this difference corroborates the 
idea that home gardens in rural and peri-urban areas play different roles in relation to family subsistence (Molebatsi et al. 2010) and that greater dependence on subsistence does not always reduce agrobiodiversity in home gardens, but modifies the agrobiodiversity (Poot-Pool et al. 2015).

Ritual plants stood out in the home gardens of the three communities studied. The historical African roots of the communities could have contributed to the presence and/ or abundance of plants from Africa or those traditionally used in Afro-Brazilian religious cults, such as Dieffenbachia amoena, Sansevieria trifasciata and Petiveria alliacea (Novais 2006), which highlights the relevance of home gardens in maintaining local beliefs and practices. In this sense, a greater historical relationship with food (such as corn, manioc, beans, and rice) and medicinal plants, as well as the importance of this form of medicine today, could be factors that contributed to these results.

Gottlieb et al. (1996) suggested there is a possible relationship between plant families cited and categories of use assigned to plant species. Based on this, the high presence of Asteraceae in the home gardens studied could be associated with the greater proportion of medicinal plants cited, because the family includes various species with active principles and is one of the most cited families in ethnobotanical studies about medicinal plants from the Atlantic Forest (Vasconcellos 2004; Pinto et al. 2006; Giraldi 2009).

For the Kalunga community, Alves et al. (2011) affirmed that the home garden is directly influenced by the relationships that occur on a larger geographic scale (e.g., plants depend on water from rivers and are influenced by global and regional climatic factors), in addition to other issues, such as the ease of acquiring food and industrialized medicine. This was also observed in the communities in Santa Catarina, principally for short-cycle food crops, such as vegetables and corn, cited by the quilombolas as being directly influenced by climate factors, and by the ease of obtaining medicine, which can influence a reduction in the use of some medicinal plants.

Alves et al. (2011) pointed out that government welfare policies might discourage food production in home gardens because this revenue could allow quilombolas to buy food in local markets, on a daily basis, and to abandon cultivating plants in their home gardens. However, in the present study this factor was not mentioned by the residents of the communities, where the lack of mills, the difficulty of combining rural living and an urban job and the lack of areas to cultivate plants are more related to the abandonment of using home gardens. It is important to note that in 2014 a food acquisition program (Programa de Aquisição de Alimentos) linked to a garden in one of the rural communities (Fortunato) was a factor that expanded local and organic farming.

Moreover, increasing commercial opportunities encourages the mass production of some crops instead of maintaining species diversity, leading to the removal of tall trees, which block the sun, and the reduction of structural complexity (Rico-Gray et al. 1990; Michon \& Mary 1994; Abdoellah et al. 2002). In the case of the quilombola communities, the higher richness of species in the home gardens of Aldeia and Fortunato, which have commercialized more of their plant resources (Avila et al. 2015), could be related to cultural values maintained over time, such as knowledge and use of plant resources for diverse purposes, knowledge about companion planting and a preference for local plant resources and artisanal products (compared to store-bought products). However, according to the quilombolas, presently many residents work for urban services and buy plants in markets, which, over time, has diminished the cultivation of plants in home gardens, as well agrobiodiversity. This has been found in other studies (Kehlenbeck et al. 2007; Chandrashekara \& Baiju 2010; Abebe et al. 2013), including the frequent substitution of cultivated plants for store-bought resources (Thompson et al. 2003; Peng \& Xuehua 2007; PootPool et al. 2012; Abebe et al. 2013).

Molebatsi et al. (2010) pointed out that in a rural area species richness is not necessarily high, but there is a greater richness of useful and native species. Other works have noted that in urban home gardens the majority of the species are sometimes introduced and, therefore, native species comprise only a fraction of the species richness (Thompson et al. 2003; Peng \& Xuehua 2007). However, the percentages of native and exotic species among the communities in the present study were similar. This result corroborates what Poot-Pool et al. (2015) observed, where the overall percentage of introduced and native shrub and tree species did not differ for rural, perirural and peri-urban areas. Overall, this could reinforce the role of home gardens in in situ conservation of biodiversity because these plants are being maintained, cultivated and selected in these environments. Even while local landscapes change and there are urbanization influences, there is still a considerable richness of native plants.

Regarding the conservation of agrobiodiversity, it is also important to note that the value of a place depends on the intimacy of human relations, so, in the absence of the right person, things and places rapidly lose significance. Therefore, it is important to explain to the studied groups the fragility of maintaining cultural practices and the management of manioc over time (Tuan 1983). Emperaire \& Peroni (2007) point out that even when management practices are made by each family unit, the local agrobiodiversity also has a collective dimension that is a common environmental cultural heritage. In the case of the Fortunato community, the resident farming manioc is 70 years old, suggesting that the practice of managing and cultivating this plant variety might disappear relatively soon.

Even though manioc has a high citation value in terms of knowledge and use, both today and historically, due to the difficulty of accessing mills the cultivation of manioc in fields has diminished and is restricted to only one person in the Fortunato and Santa Cruz communities. Among the quilombolas, the selection of less toxic species cultivated near houses was pointed out by Arroy-Kalin (2010). This was 
also found for the Aldeia and Fortunato communities, which cultivate only sweet manioc near their houses, probably because it is easier to use, and bitter manioc only in fields, together with varieties of sweet manioc. In the Santa Cruz community there was an exception because a resident had a cultivated area of both bitter and sweet manioc in their home garden, which could be linked to a lack of arable land outside of home gardens in this community.

In conclusion, unlike the results found by other authors, in the present study the home gardens in the most urbanized community were larger than the ones in the more rural communities. This is probably due to the greater representativeness of home gardens in the territory of the urbanized community that are the only place to cultivate plants. Independent of the degree of urbanization, home gardens are important locations for in situ conservation of agrobiodiversity because they are highly rich and abundant in species used for diverse means. In addition, to introduced cultivars and varieties, home gardens allow for the maintenance of native species, an important aspect to be considered when planning land distribution within the communities and the municipalities where they are located.

The diversity of food plants in the home gardens indicates the relevance of these environments as a resource for food and subsistence. Furthermore, the high diversity of medicinal plants points to the relevance of local therapeutic practices, despite the intense historical changes in the region and the greater availability of industrialized drugs (Zank 2015). The presence of plants used for rituals revealed the importance of home gardens in local traditional practices. Ethnicity could also be a factor that contributes to maintaining the practices and local cultivars used by the communities, despite changes influenced by urbanization that alter local income and the landscape.

Moreover, the home gardens of the communities are relevant in the in situ conservation of varieties of Manihot esculenta, a species of great historical importance that is being cultivated less because it has become difficult to produce the flour. This type of difficulty creates a scenario of fragility in relation to the maintenance of local intraspecific diversity and the traditional practices involved with their use and benefits.

\section{Acknowledgements}

We thank to the communities of Fortunato, Santa Cruz and Aldeia for making this research possible. Thanks to M.L.Mina (Movimento Negro Unificado de Santa Catarina) for helping with contacts; Gaia Village, S. Zank, K.M.O. Valadares, J.M Maragno, D. Herbst, M.L. Leal, G. Mirizolla, G. Pasqualetti, G.L. Antunes, M. Baumann, J. Copetti, and A. Gimenez helped during fieldwork. Thanks to CNPq for the research productivity scholarship (N.Hanazaki) and Institutional Training Program (J.V.C.Avila). Funding:
CAPES and the Graduate Program in Ecology (UFSC).

\section{References}

Abdoellah O, Parekesit B, Hadikusumah H. 2002. Home gardens in the Upper Citarum Watershed, West Java: A challenge for in situ conservation of plant genetic resources. In: Watson JW, Eyzaguirre PB. (eds.) Home gardens and in situ conservation of plant genetic resources in farming systems: Proceedings of the second International Home Gardens workshop, 17-19 July 2001, Witzenhausen, Federal Republic of Germany. Rome, International Plant Genetic Resources Institute. p. 140-160.

Abebe T, Sterck FJ, Wiersum KF, Bongers F. 2013. Diversity, composition and density of trees and shrubs in agroforestry home gardens in Southern Ethiopia. Agroforestry Systems 87: 1283-1293.

Aguilar-Støen M, Moe SR, Camargo-Ricalde SL. 2009. Home Gardens sustain crop diversity and improve farm resilience in Candelaria Loxicha, Oaxaca, Mexico. Human Ecology 37: 55-77.

Alcorn JB. 1990. Indigenous agroforestry strategies meeting farmers' needs. In: Anderson AB. (ed.) Alternatives to deforestation: steps toward sustainable use of Amazon rainforest. New York, Columbia University Press.

Alves APAF, Tomazi T, Sahr CLL. 2011. A Perspectiva etnográfica na identificação e caracterização de elementos cotidianos de uma comunidade quilombola. Observatorium 3: 79-100.

Andersson E, Barthel S, Ahme' K. 2007. Measuring social-ecological dynamics behind the generation of ecosystem services. Ecological Applications 17: 1267-1278.

Arifin HS, Sakamoto K, Chiba K. 1998. Effects of urbanisation on the vegetation structure of home gardens in West Java, Indonesia. Japanese Journal of Tropical Agriculture 42: 94-102.

Arroyo-Kalin M. 2010. The Amazonian formative: crop domestication and anthropogenic soils. Divers 2: 473-504.

Avila JVC, Zank S, Valadares KMO, Maragno J, Hanazaki N. 2015. The traditional knowledge of quilombola about plants: Does urbanization matter? Ethnobotany Research and Applications 14: 453-462.

Bellon MR. 1996. The dynamics of crop infraspecific diversity: a conceptual framework at the farmer level. Economic Botany 50: 26-39.

Bellon MR. 2004. Conceptualizing interventions to support on-farm genetic resource conservation World Development 32: 159-172.

Biesmeijer JC, Roberts SPM, Reemer M, et al. 2006. Parallel declines in pollinators and insect-pollinated plants in Britain and the Netherlands. Science 313: 351-354.

Blanckaert I, Swennen RL, Flores MP, Rosas López R, Saade RL. 2004. Floristic composition, plant uses and management practices in homegardens of San Rafael Coxcatlán, Valley of Tehuacán, Mexico. Journal of Arid Environments 57: 39-62.

Brasil. 2014. Comunidades quilombolas. Brasília, Ministério da Cultura, Fundação Cultural Palmares. http: www.palmares.gov.br/?page_ id=88andestado=sc 20 Mar. 2014.

Brito MA. 1996. Uso social da biodiversidade em quintais agroflorestais de Aripuanã - MT. MSc Thesis, Universidade Federal do Mato Grosso, Brazil.

Carniello MA, Silva RDS, Cruz MABD. Guarim-Neto, G. 2010. Quintais urbanos de Mirassol D’Oeste-MT, Brasil: uma abordagem etnobotânica. Acta Amazonica 40: 451-470.

Castro CFA. 1995. Biodiversidade e quintais. Cadernos de Proposta, Rio de Janeiro 3: 27-33.

Chandrashekara UM, Baiju EC. 2010. Changing pattern of species composition and species utilization in home gardens of Kerala, India. Journal of Tropical Ecology 51: 221-233.

Cilliers S, Cilliers J, Lubbe R, Siebert S. 2013. Ecosystem services of urban green spaces in African countries: Perspectives and challenges. Urban Ecosystems 16: 681-702.

Eichemberg MT. 2003. Os quintais antigos na área urbana de Rio Claro - SP: um enfoque etnobotânico. MSc Thesis, Universidade Estadual Paulista, Brazil. 
Emperaire L, Peroni N. 2007. Traditional management of agrobiodiversity in Brazil: A case study of manioc. Human Ecology 35: 761-768.

Emperaire L, Robert P, Santilli J, et al. 2008. Diversité agricole et patrimoine dans le moyen Rio Negro (Amazonie brésilienne). Actes Bureau Resources Genetiques 7: 139-153.

Eyzaguirre PB, Linares OF. 2004. Home Gardens and Agrobiodiversity. Washington, Smithsonia Books.

Faber M, Benadé AJS. 2003. Integrated home-gardening and communitybased growth monitoring activities to alleviate vitamin a deficiency in a rural village in South Africa. FNA/ANA 32: 24-32.

Fernandes ECM, Nair PKR. 1986. An evaluation of the structure and functions of tropical homegardens. Agricultural Systems 21: 279-310.

Fidalgo O, Bononi VLR. 1989. Técnicas de coleta, preservação e herborização de material botânico. São Paulo: Instituto de Botânica.

Florentino ELA, Albuquerque UP. 2007. Contribuição de quintais agroflorestais na conservação de plantas da Caatinga. Acta Botanica Brasilica 21: 37-47.

Galluzzi G, Eyzaguirre P, Negri V. 2010. Home gardens: Neglected hotspots of agro-biodiversity and cultural diversity. Biodiversity and Conservation 19: 3635-3654.

Garcia BNR, Vieira TA, Oliveira FA. 2015. Quintais agroflorestais e segurança alimentar em uma comunidade rural na Amazônia Oriental. Revista de la Facultad de Agronomía 114: 67-73.

Garrote V. 2002. Os quintais caiçaras, suas características sócio-ambientais e perspectivas para a comunidade do Saco do Mamanguá, Paraty (RJ). MSc Thesis, Universidade de São Paulo, Brazil.

Giraldi M. 2009. Uso e conhecimento tradicional de plantas medicinais no Sertão do Ribeirão, Florianópolis/SC, Brasil. Monography, Universidade Federal de Santa Catarina, Brazil.

Gottlieb OR, Kaplan MAC, Borin MRMB. 1996. Biodiversidade. Um enfoque químico-biológico. Rio de Janeiro, Universidade Federal do Rio de Janeiro.

Howard PL, Puri R, Smith L. 2006. A scientific conceptual framework and strategic principles for the globally important agricultural heritage systems programme from a social- ecological systems perspective. Rome, FAO.

IBGE - Instituto Brasileiro de Geografia e Estatística. 2004. Mapa de Biomas do Brasil: primeira aproximação. Rio de Janeiro. http://www.ibge.gov. br/home/presidencia/noticias/21052004biomas.shtm, 7 Aug. 2015.

IBGE - Instituto Brasileiro de Geografia e Estatística. 2012. Manual Técnico da Vegetação Brasileira. 2nd. edn. Brasília, IBGE.

Johns TJ, Sthapit BR. 2004. Biocultural diversity in the sustainability of developing-country food systems. Food and Nutrition Bulletin 25: $143-155$

Kearns CA, Inoye DW, Waser NM. 1998. Endangered mutualisms: The conservation of plant-pollinator interactions. Annual Review of Ecology, Evolution, and Systematics 29: 83-112.

Kehlenbeck K, Arifin H, Maass B. 2007. Plant diversity in homegardens in a socio-economic and agro-ecological context. In: Tscharntke T. (ed.) Stability of tropical rainforest margins. Linking ecological, economic and social constraints of land use and conservation. Berlin, Springer. p. 297-319.

Kehlenbeck K, Maass BL. 2004. Crop diversity and classification of homegardens in Central Sulawesi, Indonesia. Agroforestry Systems 63: 53-62.

Kumar BM, Nair PKR. 2004. The enigma of tropical homegardens. Agroforestry System 61: 135-152.

Kumar BM, Nair PKR. 2006. Tropical homegardens: A time-tested example of sustainable agroforestry. v. 3. Heidelberg, Springer.

List of Flora of Brazil. 2015. Rio de Janeiro, Jardim Botânico do Rio de Janeiro. http://floradobrasil.jbrj.gov.br/, 7 Aug. 2015.

Michon G, Mary F 1994. Conversion of traditional village gardens and new economic strategies of rural households in the area of Bogor, Indonesia. Agroforestry Systems 25: 31- 58.

Miller RP, Penn JW, Leeuwen J. 2006. Amazonian homegardens: Their ethnohistory and potential contribution to agroforestry development. In: Kumar BM, Nair PKR (eds.) Tropical homegardens: A time-tested example of sustainable agroforestry. Heidelberg, Springer. p. 43- 60.

MOBOT - Missouri Botanical Garden Trópicos Search. http://mobot. mobot.org/W3T/Search/vast.html, 7 Aug. 2015.
Molebatsi LY, Siebert SJ, Cilliers SS, Lubbe CS, Davoren E. 2010. The Tswana tshimo: A home garden system of useful plants with a particular layout and function. African Journal of Agricultural Research 5: 2952-2963.

Moreno-Black G, Somnasang P, Thamathawan S. 1996. Cultivating continuity and creating change: Women's home garden practices in northeastern Thailand. Agriculture and Human Values 13: 3-11.

Mosina GKE, Maroyi A, Potgieter MJ. 2014. Comparative analysis of plant use in peri-urban domestic gardens of the Limpopo Province, South Africa. Journal of Ethnobiology and Ethnomedicine 10: 35.

Niñez V. 1987. Household gardens: theoretical and policy considerations. Agricultural Systems 23: 167-186.

Nolin C. 2003. Koloniträdga ${ }^{\circ}$ rdsrörelsen i Stockholm: dess förutsättningar och uppkomst vid 1900-talets början. In: Nordiska Museets och Skansens a ${ }^{\circ}$ rsbok (ed.) Stadens odlare. Värnamo, Nordiska Museets Förlag. p. 9-40.

Novais JV. 2006. Uso de plantas nos cultos Afro-brasileiros no Distrito Federal e entorno. Monography. Faculdades Integradas da Terra de Brasília, Brazil.

Pandey CB, Rai RB, Singh L, Singh AK. 2007. Homegardens of Andaman and Nicobar, India. Agricultural Systems 92: 1-22.

Peng Y, Xuehua L. 2007. Research progress in effects of urbanization on plant biodiversity. Biodiversity Science 15: 558-562.

Peroni N. 2004. Ecologia e genética da mandioca na agricultura itinerante do litoral sul paulista: uma análise espacial e temporal. PhD Thesis. Universidade Estadual de Campinas, Brazil.

Perrault-Archambault M, Coomes OT. 2008. Distribution of agrobiodiversity in home gardens along the Corrientes River, Peruvian Amazon. Economic Botany 62: 109-126.

Pinto EPP, Amorozo MCM, Furlan, A. 2006. Conhecimento popular sobre plantas medicinais em comunidades rurais de Mata Atlântica - Itacaré, BA, Brasil. Acta Botanica Brasilica 20: 751-762.

Poot-Pool WS, Wal H, Flores-Guido JS, Pat-Fernandez JM, Esparza-Olguín L. 2012. Economic stratification differentiates home gardens in the Maya village of Pomuch, México. Economic Botany 66: 264-275.

Poot-Pool WS, Wal H, Flores-Guido S, Pat-Fernández JM, Esparza-Olguín L. 2015. Home garden agrobiodiversity differentiates along a rural-periurban gradient in Campeche, México. Economic Botany 69: 203-217.

Reis A; Boeira AF; Dametto A. et al. 2011. Lista das espécies vegetais catarinenses da divisão Angiospermas. Sellowia 56: 11-256.

Rico-Gray V, Garcia-Franco JG, Chemas A, Puch A, Sima P, 1990. Species composition, similarity, and structure of Mayan home gardens in Tixpeual and Tixcacaltuyub, Yucatán, México. Economic Botany 44: 470-487.

Saragoussi MA, Martel JHI, Ribeiro GA. 1988. Comparação na composição de quintais de três localidades de terra firme do Estado do Amazonas. Ethnobiology: Implications and Applications 1: 295-3003.

SEPPIR - Secretaria de Políticas de Promoção da Igualdade Racial. Comunidades Quilombolas. 2015. <http://www.seppir.gov.br/ comunidades-tradicionais/programa-brasil-quilombola>. 16 Jun. 2015.

Sunwar S, Thornström CG, Subedi A, Bystrom M. 2006. Home gardens in Western Nepal: Opportunities and challenges for on-farm management of agrobiodiversity. Biodiversity \& Conservation 15: 4211-4238.

Thiers, B. [continuously updated]. Index Herbariorum: A global directory of public herbaria and associated staff. New York Botanical Garden's Virtual Herbarium. <http://sweetgum.nybg.org/science/ih/>. 20 Dec. 2016.

Thompson K, Austin KC, Smith RM, Warren PH, Angold PG, Gaston KJ. 2003. Urban domestic gardens (I): putting small-scale plant diversity in context. Journal of Vegetation Science 14: 71-78.

Thrupp LA. 2000. Linking agricultural biodiversity and food security: The valuable role of agrobiodiversity for sustainable agriculture. International Affairs 76: 265-281.

Tompkins EL, Adger WN. 2004. Does adaptive management of natural resources enhance resilience to climate change? Ecology and Society 9: 10. http://www.ecologyandsociety.org/vol9/iss2/art10/

Trinh LN, Watson JW, Hue NN, et al. 2003. Agrobiodiversity conservation and development in Vietnamese home gardens. Agriculture, Ecosystems and Environment 97: 317-344. 


\section{Julia Vieira da Cunha Ávila, Anderson Santos de Mello, Mariane Elis Beretta, \\ Rafael Trevisan, Pedro Fiaschi and Natalia Hanazaki}

Tuan Y. 1983. Espaço e Lugar: a perspectiva da experiênica. São Paulo, DIFEL. UNCED - United Nations Conference on Environment and Development. 1992. Convention on Biological Diversity. Geneva, UNCED.

Vasconcellos MC. 2004. Um olhar etnobotânico para os usos dos recursos vegetais dos terreiros de uma comunidade remanescente de quilombos do Vale do Ribeira, SP. MSc Thesis, Universidade Estadual Paulista, Brazil.

Vogl CR, Vogl-Lukasser BN, Puri RK. 2004. Tools and methods for data collection in ethnobotanical studies of homegardens. Field Methods 16: 3285-306.

Williams JT. 1997. Identificação e proteção das origens de nossas plantas.
In: Wilson EO. (ed.) Biodiversidade. Rio de Janeiro, Nova Fronteira. p. 303-312.

Zank S. 2015. Saúde eco-cultural e resiliência: conhecimentos e práticas da medicina tradicional em comunidades rurais da Chapada do Araripe no Ceará e em comunidades quilombolas do litoral de Santa Catarina. PhD Thesis, Universidade Federal de Santa Catarina, Brazil.

Zank S, Avila JVC, Hanazaki N. 2016. Compreendendo a relação entre saúde do ambiente e saúde humana em comunidades Quilombolas de Santa Catarina. Revista Brasileira de Plantas Medicinais 18: 157-16.

Zimmerer KS. 1996. Changing fortunes: Biodiversity and peasant livelihood in the Peruvian Andes. Berkeley, University of California Press. 